Journal of Early Childhood Care and Education

Volume 3, No. 1, March 2020, pp. 36-48

E-ISSN 2615-1413

Open Access | URL : http://journal2.uad.ac.id/index.php/jecce/article/view/1679

\title{
The role of loose parts play in logical thinking skill in KB Lab school
}

\author{
Ega Shabrina, Anik Lestariningrum \\ Faculty of Teacher Training and Education Science, Universitas Nusantara PGRI Kediri, Indonesia \\ E-mail: anikl@unpkediri.ac.id
}

\author{
Article History \\ Submitted: February 5, 2020 \\ Accepted: May 12, 2020 \\ Published: May 14, 2020 \\ DOI: $10.26555 /$ jecce.v3i1.1679
}

\begin{abstract}
Logical thinking is a pivotal skill for children that must be developed as early as possible in order to prepare an ability to think realistic and systematic. Think logically somehow is difficult for age 3-4 years old shown by facts that some children only do activities based on teacher's example. Loose part play was selected because it facilitates creative, logical, and systematic thinking in problem solving. Loose part play is one activity that uses concrete and real object to explore. Using qualitative approach, this study involves ten students from KB Lab school. The result was analyzed using qualitative descriptive method. The data were collected using observation, interview, and documentation. The result of the study showed that the 3-4 years old children showed an improvement after playing loose part because the activities suits their developmental stage and utilized objects in their surroundings.
\end{abstract}

Keywords : children, loose part play, logical thinking skill.

Abstrak
Berpikir logis merupakan keterampilan yang harus dikembangkan pada
anak sejak dini sebagai upaya dalam menyiapkan sikap berpikir secara
realitistis dan sistematis. Permasalahan yang dihadapi anak usia 3-4
tahun masih sulit dalam berpikir logis seperti melakukan kegiatan
tergantung pada contoh yang diberikan oleh guru. Bermain loose parts
dipilih sebagai alternatif kegiatan main yang akan dilakukan karena
mengembangkan keterampilan berpikir logis, kreatif dan sistematis
dalam memecahkan masalah. Loose parts play adalah salah satu jenis
aktivitas yang memiliki kelebihan di antaranya menggunakan benda
kongkrit dan nyata sehingga anak dapat bereksplorasi. Penelitian ini
menggunakan desain penelitian kualitatif dengan subjek 10 siswa KB
Labschool. Hasil dianalisis menggunakan metode deskriptif kualitatif
dengan teknik pengumpulan data observasi, wawancara dan
dokumentasi. Keabsahan data ditinjau dengan teknik triangulasi data.
Hasil penelitian mengungkapkan bahwa keterampilan berpikir logis
subjek lebih berkembang melalui kegiatan bermain loose parts. Anak
melakukan kegiatan sesuai tahapan perkembangan dan mendapat
makna melalui bahan yang tersedia di lingkungan sekitar.

Kata Kunci : bermain loose parts, kemampuan berpikir logis, anak.

\section{INTRODUCTION}

Logical thinking in early childhood requires stimulus in the form of concrete learning materials that suit children's developmental stage. Children may exhibit greater learning interest if they like the material. Loose part play serves as a fun, meaningful learning media that suits children's development because they get direct experience when playing it. Developing 
logical thinking using loose part play is a part of scientific learning in Early Childhood Education (ECE) institutions. Contextually, logical thinking in children shows how children classify an object in terms of its function, shape or color, know about cause-effect, know ordered pattern, sort objects based on size or color (Peraturan Menteri Pendidikan dan Kebudayaan Republik Indonesia Nomor 137 Tahun 2014, 2014).

Cognitive development refers to processes including receiving, remembering concept formation, problem solving, portrayal, and consideration (Anggraini \& Suyadi, 2019). It also supports Piaget's theory (Ibda, 2015) which states that a child's developmental attainment involves important processes, namely scheme, assimilation, accommodation, organization, and equilibration. Logical thinking skill refers to children's cognitive skill to learn and understand their surroundings, this skill is used to gain information, allowing them to have an understanding of an issue they face every day (Annisa \& Hartini, 2019).

A study showed that providing 4-5 years old children opportunities about anything they saw in their surroundings, any feeling, and freedom to draw conclusion about their activities can develop their logical thinking skill. In addition, the result of the study shows that inviting children to recognize their surrounding can develop their logical skill, by doing so, children build their own knowledge and communicate it (Mardhiyatun, 2018)

Children's logical thinking skill of 5-6 years old can be developed through singing activity. Proven by a study that found out that children can easily memorize song lyrics and make a movement along with the music while singing. Singing and various creative movements supports the improvement of children's thinking ability, especially their logical thinking skill (Permatsari et al., 2019). Logical thinking may develop when children are able to communicate verbally or in writing. Logical thinking skill is closely associated with speaking skill (Iswanti, 2014). In order to make children willing to express their thought, various play designs are required. Designs that is made of their surroundings simply trigger children to directly think, see, and create.

Various studies on logical thinking skill described earlier emphasized more on playing activities that comes from the children's surroundings and utilizes natural object as the playthings (Kurniasari et al., 2018). Based on the studies above, we were interested in developing a playing activity that provide children with freedom using loose parts play. The 
concept of loose parts play is still reviewed conceptually (Putri et al., 2019). It stated that children's creative process takes place when they play loose parts. In other words, there is no research-based paper that studies about loose parts play.

There are some problems found during observation in KB Paud Labschool, such as absence of opportunity to develop children's imagination, lack of creativity, and lack of decisive attitude. Referring to (Peraturan Menteri Pendidikan Dan Kebudayaan Republik Indonesia Nomor 137 Tahun 2014, 2014), the children's problem lies in logical thinking skill. Accordingly, the author is interested to develop this skill by applying loose part play. It is assumed that loose part play can develop children's imagination, which is expressed according to their experience and develop their logical thinking skill. In addition, prior to this study, I have applied loose part play for three times, when applying this method, the children seems to be more active during learning activities. This condition may be accounted for by Piaget's cognitive theory, (Arimbi et al., 2018) which states that 3-12 years old children exhibit cognitive achievements of classifying and categorizing size when they can perform activities of making and designing various object classifications using the object in front of them. This process will serve as the basis of children's logical thinking skill, a skill the children need for their future.

Loose parts play emerges as recent issue on creative learning. Some argue that this play should be done by parents with their children, considering that most of children today spend most of their time with gadget. Considering the benefits of this activity, the idea of loose part play in preschool-aged children should be supported by many parties. Loose part play is firstly developed by an architect Nicholson (Siantajani, 2020). His work "How Not to Cheat ChildrenThe Theory of Loose Part" lies in the idea of creating an interactive environment that is in line with Piaget's cognitive concept (Ibda, 2015), which states that children have sensorimotor schemata when they were born, allowing them to interact with their surroundings. Experience emerges as the main factor that determines the establishment of that sensorimotor schemata. It may change cognitive structure, and when the experience occurs repeatedly, children's logical thinking skill can be improved.

Playing activity is also associated with cognitive processes, when children are involved in a play containing learning, motivation, meaning, self-control, and abstract-to-concrete thinking skill, this play functions to invite exploration. Play exploration and discovery learning 
activities par excellence depends on type and number of available plays (Goldstein, 2012). Loose parts play also lead to different effects on children, it depends on how teachers adjust the condition to the children's environment.

The present study involves 3-4 years old children, according to Piaget's cognitive development they were in pre-operational stage where their logical thinking skill has not possessed an organized system (Ibda, 2015). In this stage, children recognize their surrounding using marks or symbols. Grounded from this concept, loose part play emerges as a correct playing facility for children since it uses any objects around the children. It can be played and manipulated, allowing children to gain something from their play. Every activity is done within the context of playing.

Loose part concept state that loose parts play (LPP) is a technique developed to enhance children's opportunity to play by directly involving them (Gibson et al., 2017). It involves recognition of materials and tools that can be flexibly moved to other rooms, which may draw their interest. This play requires adult's instruction to improve their involvement in order to stimulate the level of discovery and creativity.

Theories on the concept of loose parts play described above is also supported by Bruner and Genova (Whitebread et al., 2017). Their study involved 3-5 years old children that were asked to engaged with objects directly, while another group were only taught about how to use the object. The result of that study showed that children with concrete experience were more intensive in designing problem-solving strategy than another group was. It proves that children's logical thinking skill, especially with regards to problem-solving, develops more significantly when they are given wide opportunities to try, explore, and directly engage with their surrounding objects.

Providing children with freedom is also done in a study conducted by giving a computer, their behaviors were assessed and is associated with their cognitive development, especially their logical thinking in solving problems. The result of that study showed that children decided to consider the game pattern based on their previous experience, they associated their previous experiences with the new ones when engaging with an object directly (Costa - Gomes et al., 2003) 
This discovery process develops their creative thinking that is a part of logical thinking skill that allows children to generate and develop idea to design a simple hypotheses, to imagine and to find out alternative answers to solve problems in an innovative manner based on available objects (Taggart et al., 2005). Learning through play facilities emerge as one key factor that determine the success of learning process because during an exploration process, every opportunity emerges as a systematic experience (Surniyati, 2019). Selecting loose parts play as a media is suitable for 3.5-4 years old children so they will be able to compare some objects within a group (Nur et al., 2018). The peak of their brain development takes places in 3-4 years old.

\section{METHOD}

The present study was categorized as qualitative descriptive study. It was conducted in KB Lab school UN PGRI Kediri, which was located in Jalan Lintasan No. 7 Mojoroto, Kediri. This study involved 10 children, consisting of 4 male and 6 female children. The data were obtained from children's activity when playing loose parts and their work. They were directly documented as the main informant. The data were collected through observation, interview, and documentation. The observation sheet was designed by the researcher and validated by the expert of Early childhood learning strategy. Data triangulation was applied to analyze the data.

\section{RESULT AND DISCUSSION}

\section{Process of applying loose part with central learning model}

Idea of theme arose when children were involved in playing activities. It was 'Myself' with subtheme 'people in my house'. Children were viewed as able to utilize all objects prepared by the teacher as shown at figure 1. Children were enthusiastic and tried to draw people in their house, and make people' head using corn kernels. Based on their imagination, they made a house miniature using blocks and playdough It shows that when children are provided with freedom to explore, the result can be beyond the target. The children told stories about what they have done. 


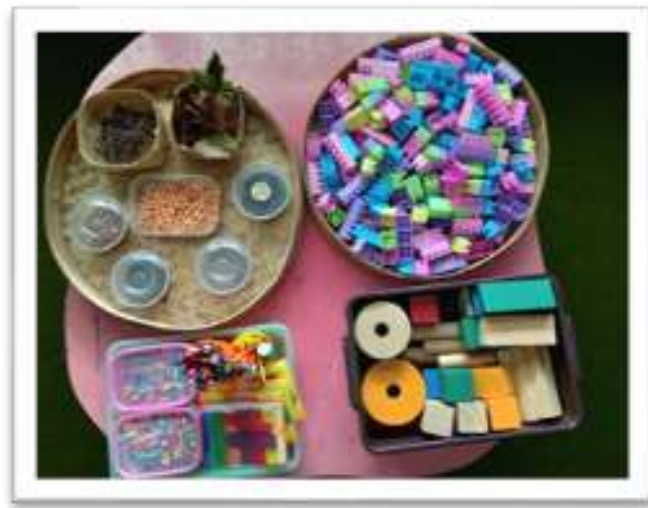

Figure 3.1. Playthings prepared for Loose Parts Play

The playthings prepared for loose play activity consisted of materials with different characteristics such as wood blocks, corn kernels, dried corn leaves, playdough, and so forth. These playthings were combined to manipulate 'parts' in order to establish new synaptic network in brain as a form of change in cognitive structure, especially logical thinking skill. By using real objects, children were expected to explore them, followed by teachers' question to see children's responses such as taking some objects, arranging, and joining the objects as shown in figure 1.2.
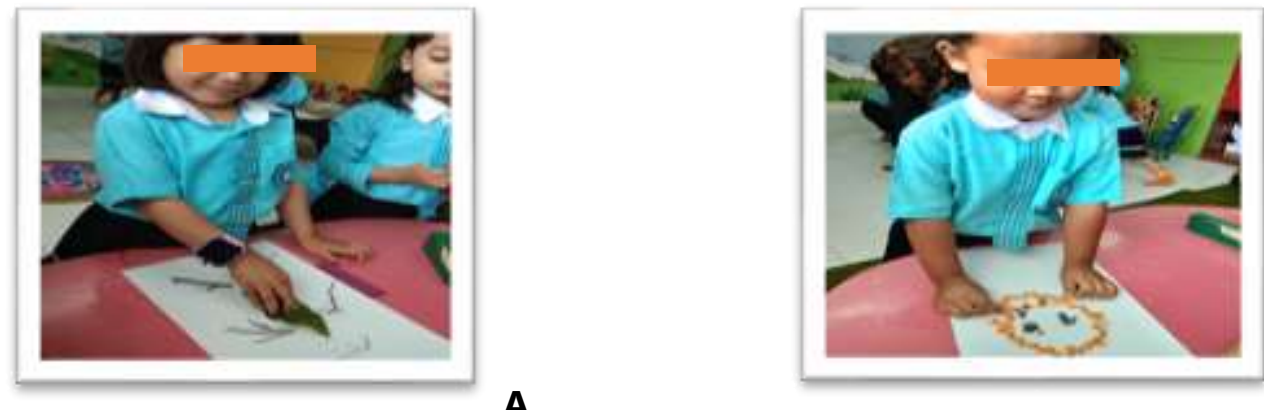

A

B
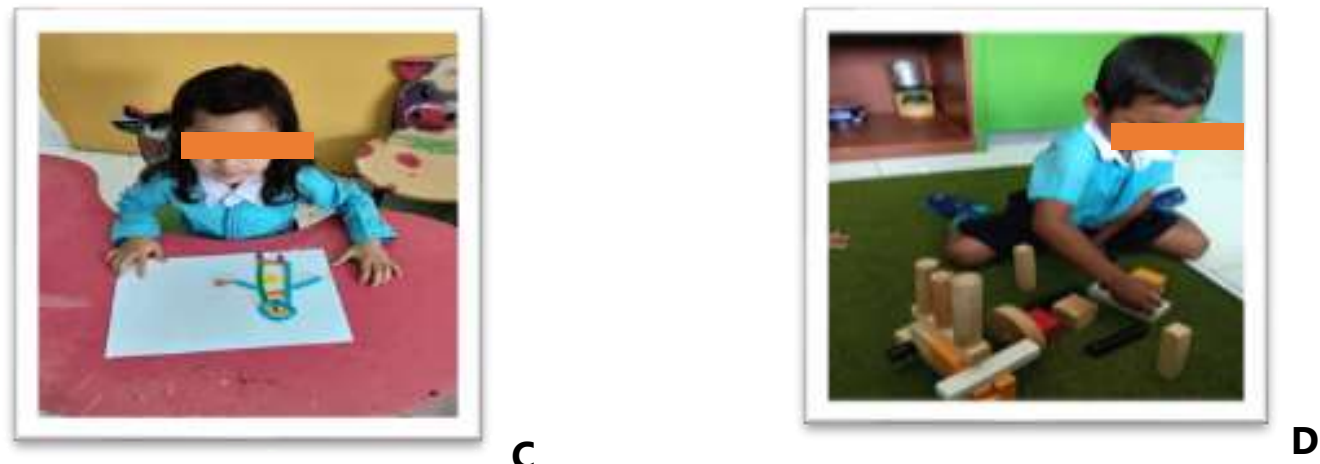

Figure 3.2. Children's activity 
In activity a) Children created figure toy by combining natural objects, the body is made from dried corn leaves, the hand and feet were made of wood stick and combined with black marker. They were free to make whether male or female figure toy. In activity b) Using corn kernels, children made human head, they used corn silk to make the hair, and used wood stick to make the mouth. In activity c) Children made a figure toy using colorful playdough. And in activity d) Children had imagination about an object, it was shown when one of them arranged the wood blocks into a shape of a house. When asked, she was making her father house in a railway station. Their creativity can be seen when they combined various forms of block to make a railway station.

Loose parts play activities described in pictures above were done in Block central classroom. PAUD Lab school UN PGRI Kediri applied central learning to design the playing environment. Its central learning model was based on individual potential development in accordance with the developmental stages. This learning model supports the loose parts play activities. However, other learning models can also support the activities. Central learning model supports loose part play method because it provides children more opportunities to play authentic, concrete objects. This indirectly teaches children to utilize objects around them.

Based on the observation results, teacher conducted simple interview with children. The teacher's questions revolve around the students' work. The teacher used open-ended questions such as a) What do you make?; b) Why do you choose the material? (child's reason); c) What do you feel after making it?; d) Tell me about the process. In order to support the result of the study, interviews were done to subject 1 ( 3 years old) as shown in table 3.1:

Table. 3.1. Result of Interview

\begin{tabular}{lll}
\hline No & Question & Answer \\
\hline 1 & What do you make? & $\begin{array}{l}\text { Miss, I like to play playdough, I will make a figure like Abi } \\
\text { (her father) }\end{array}$ \\
\hline 2 & $\begin{array}{l}\text { Why do you choose the material? (child's } \\
\text { reason) }\end{array}$ & I like it, miss. It is colorful. \\
\hline 3 & What do you feel after making it? & $\begin{array}{l}\text { I am very happy, next time give more colorful playdough } \\
\text { so I can share with friends. }\end{array}$ \\
\hline 4 & Tell me about the process & $\begin{array}{l}\text { I make an egg shape for the head, but I can't make the } \\
\text { hand, please help, miss. }\end{array}$ \\
\hline Observer's analysis result & $\begin{array}{l}\text { Mila can briefly answer the questions, in photo of activity } \\
\text { 3, she shows her work (i.e., figure toy of his father). }\end{array}$ \\
\hline
\end{tabular}


It shows that Mila already has a concept of complete person, she chose to make a figure toy of his father because she missed him because her father worked far away from her.

The answers stated by the child based on her real condition she experiences.

Interview using simple questions provide children with opportunity to answer in accordance with their thinking skill. Initially, they answered the question shortly but when more playthings were added and more activities were done, they could answer the questions using better sentence structure, besides, they began to brave to ask their friends questions about their work. When more material variations are used, children's creativity were also improved along with their experience.

Loose parts play concept can be applied to all children regardless of their ages by adjusting the level of safety for every age groups. Loose parts can be played by both boys and girls with any cultural background and different ages. It can be played indoor and outdoor with both small or big groups (Siantajani, 2020). Besides, the result of this study also support Vygotsky's theory, which states that children develop more systematic, logical, and rational concept due to the presence of social interaction (McLeod, 2018). It occurs when children are actively involved in an activity using concrete objects with their friends. When playing loose parts, assisted by adults, children build their knowledge. Learning together with other people allows them to respond to others through suggestions, comments, questions, or actions.

In Vygotsky's zone of proximal development, there is a basic question about "how" a learning process is done, where 'new skill' will be put and facilitated by a social environment. The balance between facilitating unstructured playtime for children and encouraging adult scaffolding of play will vary depending on the competing needs in individual families, but the "serve-and-return" aspect of play requires caregiver engagement (Yogman, Garner, Hutchinson, Hirsh-Pasek, \& Golinkoff, 2018). It supports the fact that variation varies depending on each children's need, however, complete play requires other people's participation to support them.

Learning activity using loose parts may establish children's logical thinking skill since it allows them to put themselves directly in the activity. Using loose parts, the essence of learning 
through play for preschool-aged children is achieved. Thus, it is important to utilize more objects from the children's surroundings. Since there is no study on loose part play for 3-4 years old children, especially with regard to logical thinking skill, we found some conceptual studies on what and how loose parts is played.

The result of this study provide an evidence that children showed logical thinking about simple classification based on certain characteristics, they showed geometric understanding, and were able to solve simple problems (i.e., making figure toy using natural materials, arranging blocks to make a railway station miniature) (Republik Indonesia, 2014). A study found that children obtain maximal results when playing loose parts in outdoor areas. It happens because the loose parts are unstructured (Flannigan \& Dietze, 2018). Outdoor view helps children found materials they need and helps them developing their imagination. Loose parts play offers various activities, children were encouraged to be innovative and to use unique ways following their personal needs and interest. Closed playthings, or unstructured, free materials require special use that will leave a space to imagine and explore elements of children's surroundings (Gull, Bogunovich, Goldstein, \& Rosengarten, 2019). It positively affects their cognitive, social, and physical development.

This study supports a previous research that stated cognitive development requires a serious attention (Retnaningrum, 2016). It is important for children to solve problems, and helping children to think logically and realistically thought a meaningful learning process can be done by simply preparing playthings from their surrounding environment. The materials for loose parts play are obtained from the surroundings, this allows children to play with their own idea to discover objects around them and use it to represent something in their mind. It is expected that future studies, using different research design, investigates further about loose parts play to support the result of the present study,

Children's direct engagement during exploration will add more knowledge of behavior and value of their environment, as well as their perception about problem-solving skill. The success of a play activities also depends on the teacher's facilitation (Anggraini \& Putri, 2019). Loose parts play will also affect children's way in building cooperative interaction in solving problems. An activity is designed together in certain situations, allowing problem-solving skill to develop from cooperative interaction (Ramani \& Brownell, 2014). Such an activity may bring 
greater contribution if it involves all children's active interaction. However, it should be emphasized that the achievement of each child varies depending on their cognitive development. Children's skill vary depending on their logical capacity

\section{CONCLUSION}

The result of this study provide an evidence that children showed logical thinking about simple classification based on certain characteristics, they showed geometric understanding, and were able to solve simple problems (i.e., making figure toy using natural materials, arranging blocks to make a railway station miniature). This result showed that the children involved in this study achieved the indicator of cognitive development. In other words, loose parts play is effective to develop children's logical thinking skill. ECE teachers are suggested to apply loose parts play to develop children's logical thinking skill because it provides children with opportunity to develop and to show their understanding of environment and culture.

\section{REFERENCES}

Anggraini, R., \& Suyadi, S. (2019). Supporting six aspects of development of children 3-6 years through educational educative tools smart book. Indonesian Journal of Early Childhood Education Studies, 8(2), 75-80. https://doi.org/10.15294/IJECES.V8I2.35973

Anggraini, W., \& Putri, A. D. (2019). Penerapan metode bermain peran (role playing) dalam mengembangkan kognitif anak usia 5-6 tahun. Journal of Early Childhood Education and Development, 1(2), 104-114. https://doi.org/10.15642/jeced.v1i2.466

Annisa, A., \& Hartini, S. (2019). Upaya meningkatkan kecerdasan matematika melalui permainan balok dalam mengembangkan aspek kognitif anak kelompok B TK Pelemgadung 3 Jaten Pelemgadung. Jurnal Ilmiah Kajian Ilmu Anak Dan Media Informasi PAUD, 4(1), 42-48. https://doi.org/http://dx.doi.org/10.33061/jai.v4i1.3027

Arimbi, Y. D., Saparahayuningsih, S., \& Ardina, M. (2018). Meningkatkan perkembangan kognitif melalui kegiatan mind mapping. Jurnal Ilmiah Potensia, 3(2), 64-71. https://doi.org/https://doi.org/10.33369/jip.3.2.119-126 
Costa-Gomes, M., Crawford, V. P., \& Broseta, B. (2003). Cognition and behavior In Normal-Form Games: An Experimental Study. Journal of The Econometric Society, 69(5), 1193-1235. https://doi.org/https://doi.org/10.1111/1468-0262.00239

Flannigan, C., \& Dietze, B. (2018). Children, outdoor play, and loose parts. Journal Of Childhood StudieS, 42(4), 53-60. https://doi.org/10.18357/jcs.v42i4.18103

Gibson, J. L., Cornell, M., \& Gill, T. (2017). A Systematic review of research into the impact of loose parts play on children's cognitive, social and emotional development. School Mental Health, 9(4). https://doi.org/10.1007/s12310-017-9220-9

Goldstein, J. (2012). Play In Children's Development, health and well-being. toy industries of europe (TIE). https://www.ornes.nl/wp-content/uploads/2010/08/Play-in-children-sdevelopment-health-and-well-being-feb-2012.pdf

Gull, C., Bogunovich, J., Goldstein, S. L., \& Rosengarten, T. (2019). Definitions of loose parts in early childhood outdoor classrooms: A scoping Review. International Journal of Early $\begin{array}{llll}\text { Childhood Environmental 6(3), 37-52. } & \text { Edution, }\end{array}$ https://files.eric.ed.gov/fulltext/EJ1225658.pdf

Ibda, F. (2015). Perkembangan Kognitif: Teori Jean Piaget. Jurnal Intelektualita, 3(1), 27-38. https://www.jurnal.ar-raniry.ac.id/index.php/intel/article/view/197/178

Peraturan Menteri Pendidikan dan Kebudayaan Republik Indonesia Nomor 137 Tahun 2014, Pub. L. No. 137 (2014). https://www.paud.id/2015/03/download-permendikbud-137tahun-2014-standar-paud.html

Iswanti, I. (2014). Pengembangan kemampuan logika sederhana melalui metode bercerita dengan media boneka jari pada anak kelompok A TK Pertiwi I Towangsan Gantiwarno Klaten Tahun Ajaran 2013/2014 [Universitas Muhammadiyah Surakarta]. http://eprints.ums.ac.id/30134/

Kurniasari, I., Sasmiati, S., \& Haenilah, E. Y. (2018). Penggunaan media alam sekitar dan kemampuan berfikir logis anak usia dini. Jurnal Pendidikan Anak, 4(1). http://jurnal.fkip.unila.ac.id/index.php/PAUD/article/view/15163

Mardhiyatun, R. (2018). Pengembangan berfikir logis anak usia 4-5 tahun di paud islam 
makarima kartasura [Institut Agama Islam Negeri Surakarta]. http://eprints.iainsurakarta.ac.id/3565/1/SKRIPSI RINI FULLTEKS PDF.pdf

McLeod, S. (2018). Lev Vygotsky. Simply Psychology. https://www.simplypsychology.org/vygotsky.html

Mehler, J., \& Bever, T. G. (1967). Cognitive Capacity of Very Young Children. Science, 158(3797), 141-142. https://doi.org/10.1126/science.158.3797.141

Nur, I. R. D., Herman, T., \& Mariyana, R. (2018). Logical-Mathematics intellegence in early childhood students. International Journal of Social Science and Humanity, 8(4), 105-109. https://doi.org/10.18178/ijssh.2018.8.4.944

Permatsari, D., Rohaeti, E. E., \& Westhisi, S. M. (2019). Meningkatkan kemampuan berpikir logis anak usia dini melalui metode bernyanyi pada anak kelompok B. CERIA (Cerdas Energik $\begin{array}{lll}\text { Responsif Inovatif 230-236. } & \text { 2(5), }\end{array}$ https://doi.org/http://dx.doi.org/10.22460/ceria.v2i5.p230-236

Putri, M. D. W., Khasanah, I., \& Kusumaningtyas, N. (2019). Loose parts play merangsang kemampuan main pembangunan anak usia dini di era society 5.0. Seminar Nasional PAUD 2019, $181-185$.

http://conference.upgris.ac.id/index.php/Snpaud2019/article/view/480/359

Ramani, G. B., \& Brownell, C. A. (2014). Preschoolers' Cooperative Problem Solving: Integrating Play and Problem Solving. Journal of Early Childhood Research, 12(1), 92-108. https://doi.org/https://doi.org/10.1177/1476718X13498337

Retnaningrum, W. (2016). Peningkatan perkembangan kognitif anak usia dini melalui media bermain memancing. Jurnal Pendidikan Dan Pemberdayaan Masyarakat, 3(2), 207-2018. https://journal.uny.ac.id/index.php/jppm/article/view/11284/pdf

Siantajani, Y. (2020). Loose Parts Material Lepasan Otentik Stimulasi PAUD. PT Sarang Seratus Aksara.

Surniyati, P. (2019). Penerapan kegiatan bermain gawang pintar dalam menumbuhkan minat dan pengembangan konsep matematika pada anak TK. Jurnal Ilmiah Pendidikan \& 
Pembelajaran, 3(3), 271-279. https://doi.org/http://dx.doi.org/10.23887/jipp.v3i3.21835

Taggart, G., Ridley, K., Rudd, P., \& Benefield, P. (2005). Thinking Skills in the Early Years:A Literature Review. National Foundation for Educational Research. https://www.researchgate.net/publication/265069159_Thinking_Skills_in_the_Early_Years A_Literature_Review

White, R. E. (2012). The Power of Play A Research Summary on Play and Learning. Minnesota Children's Museum. https://academy.schooleducationgateway.eu/documents/1508261/0/power+of+play/ec $599 a 0 c-c 9 e 5-405 d-9 c 0 c-c 65872 f e 1 e 21$

Whitebread, D., Neale, D., Jensen, H., Liu, C., Solis, S. L., Hopkins, E., Hirsh-Pasek, K., \& Zosh, J. (2017). The role of play in children's development: a review of the evidence. LEGO Fonden. https://www.legofoundation.com/media/1065/play-types-_-developmentreview_web.pdf

Yogman, M., Garner, A., Hutchinson, J., Hirsh-Pasek, K., \& Golinkoff, R. M. (2018). The Power of Play: A Pediatric Role in Enhancing Development in Young Children. Official Journal of The $\begin{array}{llll}\text { American } & \text { Academy } & \text { 1-16. }\end{array}$ https://doi.org/https://doi.org/10.1542/peds.2018-2058 